\title{
FRANCE'S FIRST CITY PLANNING LAW
}

\author{
BY FRANK BACKUS WILLIAMS
}

\section{I}

A most notable event in the history of city planning is the passage last March of the first French city planning law, the advance sheets of which are just reaching this country.

For many years France has had legislation in aid of certain details of city planning, such as, for instance, its excess condemnation laws; but none providing for the making of plans for communities as a whole, and the protection of such plans against the selfish encroachments of the owners of real property affected by them. Such laws had long since been passed in all the other great, progressive countries on the continent of Europe, and most of the smaller ones; and were to be found in the British Isles, Canada and other parts of the British Empire. The passage of the French city planning law leaves the United States-where such laws are lacking the one great exception in the progress of city planning law. Most significant of the growing realization of the importance of city planning in community life is the fact that the new French law, like the English law by recent amendment, makes the careful formulation and adoption of plans by cities and other communities compulsory.

City planning legislation has long been advocated in France. $\mathrm{A}$ bill in essentials much like the present law was introduced in the French legislature in 1909, and, somewhat changed, was passed by one of the chambers in 1916. The present law is this bill in a modified form.

The French planning law, like that of Italy passed in 1865, is a development and extension of the law for the expropriation of land, which is quite different from the expropriation legislation in England and this country. In England and here, eminent domain is judicial; in Latin countries it is a political act, the legislative or administrative authorities, after hearings at which all those interested are given full opportunity to be heard, decreeing in each case that the taking is for the public advantage, the parties deprived of their property being allowed only to litigate the amount of compensation due them. Under the older Italian and the recent French planning law, although in the main no compensation is allowed, a similar decree of public utility is required for the establishment of the plan, the proceeding being subject both to the inquiries and hearings usual in expropriations and in addition to others especially appropriate in the planning of communities.

\section{II}

Under the French planning law just passed, the following communities are required within three years of the promulgation of the present law to have planning schemes formulated and in force:

Every city of 10,000 inhabitants or over;

All the communes of the department of the Seine;

Cities of more than 5,000 and less than 10,000 inhabitants, whose population has increased more than 10 per cent in the interval between two consecutive quinquennial censuses; 
Settlements, of whatever size, of a picturesque, artistic or historic character, listed as such by the departmental commission on natural sites and monuments.

This scheme shall include:

1. A plan fixing the direction, width and character of highways to be laid out or modified and the location, extent and plan of squares, public gardens, amusement grounds, parks and the various open spaces; and indicating the reserve lands, whether wooded or otherwise, and the sites of future public buildings, utilities and other services.

2. A program of the hygienic, archæological and æsthetic servitudes to be created, as well as the other conditions to which the scheme is to be subject, especially the open spaces to be reserved, the height of structures and the provisions for drinking water, sewers, the disposition of wastes and, if necessary, the sanitation of the soil.

3. The outline of an order of the mayor, made after consultation with the municipal council, fixing the application of the above measures to the plan and program.

When any settlement of whatever size has been totally or partially destroyed by war, fire, earthquake, or any other catastrophe, the municipality shall within three months of the date of that event, draw up a general plan of building and street lines and elevations of the part to be reconstructed, accompanied by an outline of a planning scheme. Until the plan of alignment and elevations has been approved, nothing but temporary shelters shall be erected without the authority of the prefect of the department, given after consultation with the departmental planning commission provided for below.

The expenses of the required schemes and plans in the case of the communi- ties destroyed by catastrophe and those listed as picturesque, artistic or historic, shall be borne by the state; in other cases subventions may be granted in accordance with regulations to be drawn up by the state.

$$
\text { III }
$$

In each department there shall be created for the guidance of the communes of the department in their planning, a departmental planning commission composed of the local bodies in charge of hygiene, natural sites and monuments, civil buildings, and four mayors appointed by the state. This commission shall of its own motion or on their demand hear the delegates of the departmental societies of architecture, art, archæology, history, agriculture, commerce, industry and sport, the mayors of the cities or communes interested and the representatives of the transportation companies and the various utilities and services of the state.

The commission may add to its number reporters who shall be heard on the matters investigated by them. This commission shall give its advice with regard to:

1. Schemes to be adopted by the municipalities.

2. Derogations from the general principles of planning laid down by the superior commission provided for below, necessary on account of special difficulties or local needs.

3. The æesthetic or hygienic servitudes incidental to the schemes submitted to it.

4. All other matters referred to it by the prefect of the department.

At the Ministry of the Interior of the state there shall be created a superior planning commission of thirty members, composed of senators, deputies, counsellors of state, directors of various state functions and delegates 
from state societies, etc., and four city planners, architects, or others specially qualified. This commission shall establish general planning rules and regulations and shall give its advice on all schemes referred to it on its own motion or by the Minister of the Interior or the minister in charge of the "liberated regions."

When a scheme has been drawn up, it shall, after the advice of the sanitary authorities has been taken, be submitted to:

1. Examination by the municipal council;

2. The usual "inquest," preliminary to the declaration of public utility by the council of state or other state authority as required in expropriations, at which all parties interested have the right to be heard, and the objections are referred first to the municipal council and then to the prefect for opinion and preliminary decision.

3. To the examination of the departmental planning commission.

The municipal council shall then give its decision on the matter as a whole; which shall then go to the council of state or other state authority for final action, approval taking the form of a declaration that the plan is of public utility.

If in any step in the planning the city does not act, the state is given power to do so, and an appropriate penalty is visited on the city. If a scheme interests more than one commune, or transcends the department, intercommunal or interdepartmental action and control are provided for.

Anyone creating or developing a group of houses is required first to deposit the plan with the authorities and obtain the approval of the prefect of the department.

After a plan is declared to be of public utility, or in the case of private developments is approved by the prefect, the owners of lands abutting on proposed highways or squares shall conform to the lines established and shall not erect new structures without a permit from the mayor. 